\title{
A review of accounting basis adjustments
}

\author{
Mojtaba KARBASIAN \\ MA student of accounting, Allame Tabatabayi University, Tehran, Iran
}

\begin{abstract}
Governmental accounting and national accounts are two types of reporting system as interrelated with different purposes. The financial data of public institutes are provided in public accounts by the governmental accounting system. The public accounts are the initial data of national accounts. This issue is of great importance in European Union as these reported values are considered as the main measure of monitoring the monetary policies of Euro. As the national accounts reporting is based on accrual system in accordance to European system of national and regional accounts, the governmental accounting system of different countries has its own special reporting system and the cash basis in the budget reporting is combined with the accrual basis in financial reporting. Thus, in case of converting the data from the governmental accounting to national accounting, we need some adjustments in audit basis. This study explains and compares the governmental accounting with national accounts and different analyses in their accounting basis to perform adjustments on the estimations of governmental accounting data to compute the macroeconomic ratios including budget deficit and it is effective on reliability and comparability of data. Also, similar researches are applied in different countries.
\end{abstract}

Keywords: Governmental accounting, National accounts, Cash basis, Accrual basis, Budget reporting

\section{Introduction}

Recently, the progresses on national and governmental accounting have increased the wide range of two types of accounting. In national accounting, to evaluate the basic factors of economic activities of a country, the financial reports of governmental accounting are used for socioeconomic analyses. The main purpose of national accounting is the classification of economic and financial activities in the public and private sectors to present a complete image of structure, combination and national economy activities including production, distribution and consumption of goods and services, wealth and income of the country. In the governmental accounting, providing the data is discussed in determination of national capital (the goods and comprehensive human resources), national production (the value-added of all economic sectors, national income, national consumption and national saving) and national product (the sum of local productions).

The governmental accounting is one of the basic tools of financial management of government and includes registration and classification of financial activities of government and state 
organizations (namely the financial activities of implementation of the approved budget) in independent accounts and providing the relevant financial statements. Generally, the main purpose of the governmental accounting is providing the required facilities for good planning and budgeting of programs, activities and the government plans via presenting the classified financial data regarding the financial activities of the public organizations. Thus, the registration of all accounts receivable, accounts payable, revenues and costs, assets and debts of the public systems and keeping the documents showing the legitimacy of their financial activities and classification of financial data as useful for the management and control are the main duties of the governmental accounting system.

In recent years, the goals of the governmental accounting are developed considerably with the growth of state sector and economic development of countries. To increase the efficiency of the public organizations operation, besides computation intentions, national, political and economic intentions are the necessary items in holding the public accounts. The economic and financial analyses are possible if the public accounts are directly associated with national accounts. The public accounts provide the raw data of national accounts with the aim of presenting the production, consumption and national saving in a general framework. By making appropriate changes and adjustments in the governmental accounting basis, we can regulate the national accounts with general intentions compared to that of the governmental accounts and the existing differences in accounting basis include the adjustments of governmental accounting data estimations to compute the macroeconomic ratios including budget deficit as effective on reliability and comparability of data. This study is based on library and content analysis method. Also, the present study explains and compares the governmental accounting and national accounts and also emphasizes on a unified accounting basis for financial reporting at micro and macro level to increase the reliability of output data including the budget deficit.

\section{Statement of problem}

National economy or macroeconomics includes providing the productions, revenues and balance sheet accounts in the main sectors including government. The data is collected to evaluate the performance and national economy. The macroeconomics is formed based on the international standards and the frameworks designed by some organizations including US government and IMF. National accounting as called economic or macro accounting provides a comprehensive framework in which the data are stored and then are designed as they are applied in economic analyses, decision making and policies (Stenton et al., 1998).

The national accounts system is a comprehensive accounting framework applying the uniform concepts of accounting to summarize the economic events to present a general image of economic activities. This accounting system provides the required conditions to monitor the financial condition and national development trend by the nation and the development condition of a country is compared with other countries (Babajani, 2005). 
National accounts are statistical systems focusing on 5 sections in a unified economic system. Two sectors are dedicated to business activities (financial and non-financial companies), one sector to non-profit institutes, another sector to the families and government (The public sector of government). For all these sectors, governmental accounting is applied (Jones and Loder, 1996; Jones, 2000; Marty, 2006). The performance of this system is based on a conceptual and economic framework and it is used in economic activities in a country or among some countries around the world. The goal of this system is prediction and description of macroeconomic scales including GDP, trade growth, national income, consuming revenue, saving and consumption in a country and the interaction among the different economic institutes (Pose, 2008; The board of international governmental accounting standards, 2012; Vanoly, 2005).

Establishing a system of national accounts was not possible before the Second World War .A uniform international system was developed in 1953 and it was revised during 1960-1993 (Jones, 2000; Vanoly, 2005). In 2008, an updated version of national accounts system was published and considered as a statistical framework presenting a comprehensive, integrated and flexible set of accounts of macroeconomic level for policy making and analysis goals. The national accounts system 2008 should be applied for all countries and it considered all requirements of different countries in different economic development levels.

The national accounts system was resolved in Europe assembly NO. 2223.96 and all member countries of this union were obliged to accept European system of national and regional accounts to provide national accounts. Since April 1999, the entire data submitted to the statistic center of EU have been in accordance to this system. In addition, based on the European system of national and regional accounts 95 , one of the purposes of this system is the control of monetary policies of Europe and macroeconomic scales as budget deficit and debts. Thus, national accounts to support monetary and budget policies are considered as the best systems for convergence at macroeconomic level as this system provides the governmental financial statistics (Barton, 2007, 2011, Hoke, 2005, Kening and Tengeran, 2004, Loder, 2000). The governmental accounting is a type of financial reporting presented by the state sectors and it includes useful information for decision making on the allocation of rare resources (Stenton et al., 1998).

Regarding the problem of adaptation and the relationship between national and governmental accounting, Golomboling states that at macro level, there are different views on economy and national income account is only computed by referring to the rules. These rules are based on the data or political views regarding the value and significant of this item (Golombling, 1974). If these two systems present useful information about the economic performance of government as an institutional unit, it should be formed based on the similar theories and evaluations. In addition, the storage of data and their processing are useful on the condition that these two accounting systems are comparable. If the governmental and national accounts have similar definitions or are formed based on accrual accounting with similar assessment methods, the adaptation and comparison are possible (Stenton et al., 1998). 
In the relationship between governmental accounting and national accounts, the main concern is converting the data of public sector of government to the national accounts and they are achieved based on the budget information of governmental accounting. Also, the diversity and divergence of macro accounting systems are exposed to ambiguities as relevance, reliability and comparability of data and indices to take decisions of the EU members (Batito and Bastida, 2009; Loder, 2000). Some of the review literatures emphasize on the differences of recognition criteria. Normally, in national accounts, accrual basis is used but diverse accounting bases are used in governmental accounting and they normally use accrual basis for their financial systems and cash basis and adjusted cash basis for budget systems (Barton, 2007; Kordes, 1996, Jones and Loder, 1996; Marty, 2006; Montison and Vela, 2000, Tores, 2004).

The board of international governmental standards presented a working plan regarding the difference between governmental accounting and national accounts and convergence was made between the international governmental standards and national accounts system. A research report was published in January 2005 with the aim of identification of the difference between financial reporting of accounting systems based on national accounts and reported financial information by governmental accounting. In this report, special attention is given to the required adjustments provided by governmental accounting of the state sectors and this leads to different measures as assets, debts and reduction of reliability of macro-economic indices.

IFAC states the objectives of national accounts and the government statistics system and their relationship with the governmental financial reports as follows:

1- The national accounts measure the net wealth of the entire country as government is a part of it. The reporting unit of national accounts is the entire society and the government statistics is a special system analyzing the governance activities of the government and the reporting unit in this system covers only the public activities of the state sector.

2- The governmental financial reporting is performed in each of governmental sectors. The reporting of the government statistics system is a set of governmental reporting unit and the public sector of government is a part of national economy.

3- As national accounts and the government statistics system are closely associated to each other, the analysts evaluate the changes of the public sector of the government with a wide economic framework. The financial information of the governmental reporter unit should be as being applied in three types of reporting system. The national accounts and the governmental statistics system apply accrual basis and the government financial reports should be provided based on the accrual basis.

4- The different measurement goals in national accounts and the government statistic systems require a separate classification and standard.

5- The assets classification is different in national accounts and the governmental statistics system.

6- The national accounts emphasize on the measurement of production and net wealth in the economy of countries and the governmental statistics system doesn't emphasize on 
production and its main goal is the identification of useful financial resources to analyze the governments' financial performance (Babajani, 2005).

As the accounting system and financial reporting of government are the tools to perform the governmental accountability, the significance of the financial accountability of public sector is as it is used as the major feature of the new management of public sector (Jesoza, 2013). It is assumed that the financial reports provided by information system of governmental accounting provide useful information for citizens regarding the performance of government and consumption of different resources.

Based on the extensive duties, activities and plans of government, it is necessary to provide an accounting information system and uniform governmental financial reporting to perform financial affairs of government and accountability. Such a system can help the managers to take logical decisions to achieve the organizational goals. Based on the changes made in the classification of budget items and its classification based on financial statistics system and legal obligations of establishing an operating budgeting and goods and services costs, establishment of an accrual accounting system is necessary. Thus, it is required to take some steps to approach to the international standards of governmental accounting. In addition, based on the approach of the committee of accounting standards of public sector in Iran in localization of international standards of governmental accounting, and provide a good ground for operationalizing these standards.

\section{Review of literature}

Various researches have been conducted on the application of accrual basis in accounting in Iran and other countries.

Antonia,M , Jorge,S (2016) in the study "Accounting basis adjustments and deficit reliability" showed different analyses in accounting basis between government accounting and national accounts and the required adjustments in converting the data of government accounting to national accounts. Also, they used the evidences of three southern European countries (Portugal, Spain and Italy), with cash-based budgetary reporting, and where budgetary deficits have been particularly significant in the latest years - to show how diversity and materiality of these adjustments may question the reliability of the budgetary deficits finally reported in national accounts. The main findings point to the need for standardized procedures to convert cash-based into accrual-based data as a crucial step, preventing accounting manipulation, thus increasing reliability of informative outputs for micro and macro purposes.

Antonia,M , Jorge,S (2014) in the study " From governmental Accounting into National Accounts " evaluated the governmental accounting and national accounts and applied the evidences of lberian Countries Central governments. They found that as budgetary reporting was provided based on cash basis, national accounts were provided based on accruals. Thus, these two systems should be combined and the governmental accounting system called budgetary 
reporting system couldn't meet the requirements of European systems of national and regional accounts.

Talebnia, Dr. Ghodratollah, Alborzi, Dr. Mahmoud, Zarei and Batul (2011) in a study "A contingency model for transition from cash to accrual basis in governmental accounting of Iran" emphasized on the important role of reforms consultants namely committee of governmental accounting standards and chartered accounts and auditors and found that the prediction of good approach of reforms in governmental accounting in Iran was based on accrual accounting with management-based and accountability approaches. Also, the combined, authoritative, participative, phased and part strategies were the best strategies for governmental accounting reforms. Based on the study findings, the political environment had the highest impact on reforms and it was proposed that the ministry of economics and assets affair as the authority of policy making attracted the attention of policy makers to the significance of the reforms and their political participation.

Azizgard and Karimi (2011) in the study "Evaluation of the effect of changing cash accounting method to accrual accounting on the financial and operating performance of Medical Sciences University of Shahid Beheshti" evaluated using accrual accounting and found that establishing a full accrual accounting and operating budgeting played important role in improving financial performance and operating performance of the Medical Science University of Shahid Beheshti.

Talebnia, Ghodratollah, Zarei and Batul (2011) in a study "The impact of environmental factors on the process of governmental accounting reforms in Iran via contingency model" evaluated the current condition of governmental accounting in Iran. They found that besides the global requirements in the country, for some various reasons namely operating budgeting, accrual accounting is a necessary. Based on the study findings, the governmental accounting of Iran was on the verge of a dynamic change and this change was motivated by the increase of demand was the legal requirement regarding the budget operation. A contingency model was used in the prediction of future reforms in Iran and emphasized on the predictability power of Loder model.

Rafie, Afsane (2011) in a study "Evaluation of the changes of governmental accounting and budgeting in Eastern and central Europe" introduced Eastern and central European countries and had a review of rules joining EU in budgeting and financial management of the public sector and the main motivations of changes in the east and center of Europe using Loder contingency model.

Heidari, Ramezan, Bagherabadi and Seyed Mohammad (2011) in a study "A critical analysis of the change of cash accounting system to accrual accounting in local governments and Italy municipality" evaluated the conversion of accounting system from cash to accrual and found that this change was weak regarding some local governments and cash accounting was better than accrual accounting. Also, less emphasis was on the quality of accrual accounting and expenditure accounting systems were the priorities of the local governments rarely. The full accrual system in 
budgeting and reporting and comprehensive use of performance criteria and the lack of using traditional system of cash accounting were presented.

Babajani, Jafar, Bozorgasl, Musa, Banani, Mehdi, Safayinasab, Abdollah, Mahdavi, Gholamhossein, Safar, Mohammad Javad (2011) in a conference "The challenges of formulation of governmental accounting standards" evaluated the selection of a good accounting basis (cash, accrual, adjusted accrual) and a good measuring approach in governmental accounting standards in Iran.

Hamid Molania Jelodar (2010) in the thesis "The evaluation of profitability of accrual accounting in the reporting transparency and increasing accountability of public sector in Iran" tested some hypotheses and the results are as:

1- The results of the first hypothesis test show that implementation and execution of accounting, accountability and reporting transparency are effective simultaneously. Thus, we can say the implementation of accrual accounting system in accounting system of public sector in Iran can increase the transparency of reporting and accountability of public sector.

2- The results of second hypothesis test show whether the implementation of accrual accounting can increase the reporting transparency independently without considering the accountability or not. Based on the results of this hypothesis test, the respondents support this hypothesis with high percent and the accrual accounting system can increase reporting transparency and transparency of the costs of activities.

3- The results of third hypothesis test show that implementation of accrual accounting in the public sector of Iran are effective on the factors of accountability. Thus, we can say implementation of accrual accounting system in the public sector of Iran can improve accountability.

Babajani, Jafar, Madadi, Arezoo (2009) in the study "Feasibility of change in accounting system and financial reporting of state Universities of Iran" evaluated the feasibility of establishing accounting system based on adjusted accrual basis and the economic resources in Universities and higher and research education institutes. They found that all incomes of these institutes except the revenue of researches have measuring (required condition) and collection capability (adequate condition) and we can use the adjusted accrual accounting basis to identify the revenues and accrual basis regarding the costs in Universities and higher education institutes.

Rafie, Afsane (2008) in the study "Application of full accrual basis in governmental accounting" evaluated the different bases of accounting and using full accrual basis in the state sector in Australia and its benefits and found that accrual accounting could reflect the long-term financial condition and the entire financial condition. This system led into the increase of accountability of the government to the beneficiaries in different fields. 
Babajani and Jafar (2006) in the study "The necessity of using accrual accounting in the public sector and its evaluation to be used in the public sector of Iran" evaluated using accrual accounting and found that accounting system and financial reporting had important role in accountability to increase the claims of citizens. We can say the foundation of the mentioned system is full accrual basis or minimum adjusted accrual basis.

Biondi, Y (2016) in a study "Accounting representations of public debt and deficits in European central government accounts" evaluated accrual accounting in the public sector and its relationship with budget deficit. He found that in the governmental accounting system, to present financial reporting and fulfillment of accountability, we need to use accrual accounting basis in the budget and show the costs namely non-cash costs including depreciation and reward of pension services.

Tickell, G.(2010) in a study "Cash to Accrual Accounting: One Nation Dilemma" evaluated the application of accrual accounting and its barriers. He found that despite the necessity of using accrual basis, some problems as low-skilled public service, complex software and low skill of accountants had weakened the use of accrual basis.

\section{The summary of evolution of governmental accounting in five Anglo-American countries}

Budget deficit (1970, 1980), minor committee of public sector (1981), two-digit inflation (1983), reduction of credit rank of life style (1983), selection of labor party (1984), conversion of the committee in 1981 to accounting committee of public sector (1984), formation of public financial law (1989), technical guidance by public sector accounting committee (1988-1991), issuing the first financial statements based on accrual basis as the first country (1992), approving the separated standardizing method for the public sector (1993), formation of the board of accounting standards (1993), the decision of the board regarding taking international standards of financial reporting (2002), replacing the external organizational reporting board with the board of accounting standards (2011).

Economic stagnation of Australia as economic growth barrier (1970), selection of labor party government (1983), formation of the board of accounting standards of public sector (1983), The formation of the board of accounting standards by government to evaluate the standards formulated by the profession and publishing them (1984), the obligation of the new government of southern Wales regarding the transfer of the public sector to the private sector (1988), stating a national government regarding taking accrual accounting (1992), presenting all financial statements of sectors based on accrual accounting (1994), providing financial statements of the entire government based on accrual basis (1996), combination of the board of accounting standards with the board of profession accounting standards (1988), the board of accounting standards as the board of Australia accounting standards as renamed (1991), the integration of the board of accounting standards of public sector and the board of Australia accounting standards (2000), the decision of financial reporting board regarding taking the international financial reporting standards (2005) and formational of three standards of public sector by the board of accounting standards of public sector (2008) 
The emergence of public sector management (1980), extensive application of accrual accounting (at the same time with using private sector accounts by the hospitals of national health services)(1999), supervision of the minister of asset of accounting and budgeting of resources as extensive compared to the accrual accounting (1993), present accounting and budgeting of the government resources based on accrual accounting (1994), formation of a consulting board of financial reporting for consultation in using the principles accepted to treasury (1996), selection of labor party (1997), using accrual accounting for England government (2000), the decision of the board regarding taking international financial reporting standards (2009-2010) and present non-audited report of government sector by treasury (2011).

Formation of national committee of urban accounting (1933), The need to various economic enterprises in central government (1950), the pressure to provide financial statements based on accrual basis (1970), formation of the board of accounting standards of public sector under the supervision of financial accounting foundation (1984), creating a memorandum of understanding to create the board of accounting standards of central government (1995), the publishing of the statement NO. 34 of the board of accounting standards of public sector (1999) and publish the statement NO. 44 of the board of accounting standards of public sector (2004).

The commitment of the minister of asset to evaluate the program (1994), explain the intention of the central government to move to the accrual accounting (1995), formation of Glassco committee for governmental organizing activities (1962), formation of Lambert committee for financial management and accountability activities (1979), formation of the board of governmental accounting standards by the chartered accountant association in Canada (1975), The need to the agreed reporting standards for governments in Canada (1980), formation of the committee of accounting and audit of public sector (1981), Provide the first audited financial statements based on accrual accounting (2003) and the obligation of the board of standards of public sector in using accrual accounting (2005-2006).

\section{Conclusion}

Governmental accounting and national accounts are two types of reporting systems as interrelated with the different goals. This issue is of great importance in European Union as these reported values are considered as the main measure of monitoring the monetary policies of Euro. As the national accounts reporting is based on accrual system in accordance to European system of national and regional accounts, the governmental accounting system of different countries has its own special reporting system and the cash basis in the budget reporting is combined with the accrual basis in financial reporting. Thus, in case of converting the data from the governmental accounting to national accounting, we need some adjustments in audit basis. The basis of accrual accounting is implemented in some of Iranian executive systems including ministry of health, treatment and medical education, ministry of sciences, research and technology and Municipalities. The government attempts to convert cash basis to accrual basis in all executive systems in future. To achieve this goal and approaching the national accounting basis (accrual), besides the reformation of some rules for exact control of revenues and other credit revenues, costs and payments require the education of human resources, development of communicative infrastructures, revision of accounting instructions with accrual approach. Based on the benefits 
of accrual accounting (Increase of accountability, information transparency, optimized allocation of resources, etc.), by transition from cash accounting and budgeting, we can move to accrual accounting and operating budgeting and pave the way for the reporter to increase accountability, transparency and productivity in the public sector.

\section{References}

[1] Kordestani, Qolamreza, Kazem Shirazi, Samane. 2014. The evolution in theoretical framework of financial reporting of public sector. The accrual accounting and the effect of economic conditions. Auditor. P. 61-67.

[2] Tavusi, Mohammad Reza; Tavusi, Samane; Hassani Alghar, Masoud, Poraskar, Khaje Khezri, Fateme. 2013. The comparison and adaptation of national accounting and governmental accounting. Financial management and investment. Golestan province. Gorgan.

[3] Babajani, Jafar et al., 2013. The theoretical basics of accounting and financial reporting of Municipalities. The city publishing center.

[4] Talebnia, Dr. Ghodratollah. Alborzi, Dr. Mahmoud, Zarei, Batul. 2011. Present a contingency model for transition from cash basis to accruals in governmental accounting in Iran. The journal of accounting knowledge. Year 2. No. 5. Pages 51-73.

[5] Azizgard, Karimi. 2011. The evaluation of the effects of changing cash accounting to accrual accounting on financial and operating performance. The medical science University of Shahid Beheshti. Auditor. New period. Year 11. N 4, p. 19.

[6] Talebnia, Ghodratollah; Zarei, Batul. 2011. The evaluation of the effect of environmental factors on governmental accounting reforms process in Iran via contingency model. Management accounting. NO. 9. P. 57-68.

[7] Rafie, Afsane. 2011. The evaluation of the changes of governmental accounting system and budgeting in Eastern and Central Europe. Auditor. No. 55. P. 90-100.

[8] Heidari, Ramezan; Bagherabadi, Seyed Mohammad. 2011. A critical analysis of the change of cash accounting to accruals in local governments and Italy Municipalities. City economy. NO. 9. P. 130-135.

[9] Babajani, Jafar. Bozorgasl, Musa. Banani, Mehdi, Safayinasab, Abdollah. Mahdavi, Qolamhossein, Safar, Mohammad Javad. 2011. Conference, The challenges of formulation of governmental accounting standards. The journal of auditor. NO. 55, p. 30-45.

[10] Hamid Molania, Jelodar. 2010. The evaluation of the usefulness of accrual accounting in the transparency of reporting and improving accountability of public sector in Iran. Thesis of Azad University of Tehran Markaz.

[11] Babajani, Jafar, Madadi, Arezoo. 2009. The feasibility of changes in accounting system and financial reporting of governmental Universities of Iran. The accounting and audit. NO. 56, p. 3-20.

[12] Afsane Rafie. 2008. The application of full accrual basis in governmental accounting. Journal of auditor. NO. 40, p. 86-91. 
[13] Babajani, Jafar. 2006. The necessity of using accrual accounting in the public sector and its assessment to use in the public sector. Peikenoor, Fifth year. NO. 4. P. 6.

[14] Babajani, Jafar. 2005. The new financial reporting in the public sector. Audit. NO. 17, 18.

[15] Antonia, M $\leq$ Jorge,S(2016). "Accounting basis adjustments and deficit reliability: Evidence from southern European countries". Revista de contabilidad- Spanish Accounting Review 19,pp 77-88.

[16]Biondi, Y (2016). “Accounting representations of public debt and deficits in European central government accounts : An exploration of anomalies and contradictions ". Journal homepage, www.elsevier.com/locate/accfor

[17] Antonia, M ؛ Jorge,S (2014). "From governmental Accounting into National Accounts : Adjustments Diversity and Materiality with Evidence from the lberian Countries Central governments". Rew .INNOVER JOURNAL, VOL 24, PP. 121-138.

[18] Tickell, G.(2010). "Cash to Accrual Accounting: One Nation Dilemma”. The International Business and Economics Research Journal, Vol.9, Issue.11, pp.71-79. 